\title{
The Presence or the Absence of Schools: What Impact for Rural Communities in Hungary and Romania?
}

\author{
Zsuzsanna KASSAI ${ }^{1}$, Cristina-Bianca POCOL ${ }^{2}$, T. FARKAS ${ }^{3}$ \\ ${ }^{1}$ Institute for Regional Economics and Rural Development, Szent István University, Hungary \\ ${ }^{2}$ Department of Economic Sciences, University of Agricultural Sciences and Veterinary Medicine, \\ 3-5, Mănăștur Street, 400372, Cluj Napoca, Romania, \\ ${ }^{3}$ Institute for Regional Economics and Rural Development, Szent István University, Hungary \\ *corresponding author, e-mail: cristina.pocol@usamvcluj.ro
}

Bulletin UASVM series Agriculture 73(1)/2016

Print ISSN 1843-5246; Electronic ISSN 1843-5386

DOI 10.15835/buasvmcn-agr: 12020

\begin{abstract}
In rural communities, a school can be defined as an 'axis mundi'. Besides providing basic education, the school represents an important cultural and social pivot. The aim of the study was to identify the links between the characteristics of rural areas in Hungary and Romania (population characteristics, employment and welfare characteristics, housing and infrastructure characteristics) and the school closure phenomenon. Secondary data were analyzed in order to describe the situation of each country. The preliminary results revealed problems related to the decrease of schools' number, due to the unfavorable demographical situation and to the consolidation process. Despite the ambiguous findings, it is possible to say that rural communities with schools have a higher level of welfare. Even though in both countries school closures had a negative impact on the community, it is not implied that in those communities the worst living conditions were recorded. A limitation of the current study was the lack of the same set of variables for the two countries, which made difficult the comparison between them. Further research is needed in order to find out new correlations and interrelations and to prove them as statistically significant.
\end{abstract}

Keywords: education, school closure impact, social capital, rural space

\section{INTRODUCTION}

The problems regarding education can be interpreted in both urban and rural contexts. Rural school closures can be significant factors of social stratification, as explained by Mincu (2011): "In post-communism, in spite of some development policies and programs, new economic, administrative, financial and educational restructuring through decentralization mainly contributed to maintain and produce new stratification effects". Closing rural schools is a worldwide-known problem. A rural school represents much more than an educational institute, providing economic and social opportunities, playing the role of an arena for local politics, a delivery point for services and a resource for community development. Lyson (2002) agrees with the above-mentioned statements: according to him, schools in rural communities play many roles. They provide basic education, they serve as social and cultural centers. For rural communities, the school is not only the social hub of the village, but also an important element in the cultural development of the community (Lyson, 2002).

The negative effect of school consolidation is that it can cause divisions within and between rural communities, especially when there is competition between schools for pupils. The economic impact is also important. Parents are inclined to spend more money locally if their children are in a local 
school; on the other hand, closing the school is difficult to explain from an economic point of view. Hungarian studies proved that, per capita, the costs of small schools are quite high for under 100 pupils. In addition, there is no evidence of significant difference in terms of efficiency between small and big schools. The differences can be traced back to the differences of the educational level of the parents (Bódi and Fekete, 2011). Poverty is connected to the problems of the educational system. In Romania, the number of children who dropped out of school has tripled between 2000 and 2007 according to UNICEF (2012). The financial crisis in 2008 speeded up this process. Budget cuts lead to the shut down of many schools in rural areas, making it hard for children living in isolated villages to get to school. Many qualified teachers have quit, being often replaced by under-qualified beginners (Popa and Acedo, 2006).

In his study, Lyson (2002) explains why it is necessary to document and quantify what a school means to small rural villages. This paper has the attention of policymakers, educational administrators and local citizen focus on the importance of schools to the appropriate operation of rural communities. It is established that the presence of a school in small villages is associated with many social and economic benefits, like higher housing values and more developed municipal infrastructure. Therefore, the author concludes that the gain of a school consolidation can be lost in decreasing taxes, declining property values and lost business (Lyson, 2002). Autti and Hyry-Beihammer (2014) have examined school closures in Finland, focusing on the social role of small village schools. The number of school closures has remained high since 1992, and the number of small schools has decreased significantly. Their interviews underline the fact that local residents were unanimous about the significance of village schools. A safe, small school is fundamental to a pleasant community. A school represents much more than just a place to educate children: it influences the community's welfare. In addition to generating human and cultural capital, schools generate and reinforce social capital. Schools in rural areas are centers of the village's social life and have a crucial role in constructing a local identity (Autti and Hyry-Beihammer, 2014).

Howley et al. (2011) recommends deconsolidation instead of consolidation in order to increase the fiscal efficiency and educational quality in many big schools. They established that the academic and social performance of schools with too many enrolled pupils has been decreasing. They claimed that the benefits of school and district consolidation were overestimated. More than that, their studies show that small schools and districts might suffer irreversible damage in case of consolidation. On the other hand, they underline the fact that the benefits of deconsolidation can be judged only on a case-by-case basis (Howley et al., 2011).

\section{MATERIALS AND METHOD}

The goal of the paper is to identify the characteristics of the community associated with the presence or absence of a school. With the help of different socio-economic indicators, the study analyzed the causes of school closures and their impact on rural settlements. In both countries - Hungary and Romania - the rural context of consolidation was analyzed. For Hungary, the definition of Hungarian Rural Development Program for rural areas was used. According to this document, Hungarian settlements with a population density below 120 persons $/ \mathrm{km}^{2}$ and with less than 10,000 inhabitants are considered rural areas. 2,766 Hungarian villages $(88 \%$ of the settlements) met these requirements. In case of Romania - the National Rural Development Programme 2014-2020 of $1^{\text {st }}$ July, 2015 highlights that rural areas represent an important part of the whole territory, about 87,1\% (PNDR, 20142020). According to the National Institute of Statistics (2012), the rural area comprises 2,861 communes, formed by grouping several $(12,957)$ villages. The Hungarian database comprised only villages with less than 2,000 inhabitants since in villages with a higher number of inhabitants, there are schools. Therefore, it was decided to focus on settlements of that size. Then, two subsets of data were created in order to avoid the influence of the population size criterion on the research findings. The first set included small-sized villages with 500 or fewer inhabitants while the second one focused on small and medium-sized villages with a population between 501 and 2,000. In 2013, 1,062 villages ( $34 \%$ of the settlements) counted 500 or fewer inhabitants and 1,233 villages (39\% of the settlements) a population between 501 and 2,000. Unfortunately, there was not possible 
to collect the same set of variables in Romania. The comparative research was based basically on the indicators being available in both countries. Demographics, employment rate, welfare, housing and infrastructure indicators were selected. Secondary data for the analysis were mainly obtained from censuses and some other territorial databases of the national statistical institutes of Hungary and Romania. For data processing, statistical methods were used, applying Excel and SPSS programs.

\section{RESULTS AND DISCUSSION}

\section{Socio-economic circumstances of school} closures in Hungary:

Despite the differences in size and the presence or absence of a school, the demographic characteristics of all Hungarian rural villages are quite similar (Table 1). For instance, indicators age structure and school qualification are almost the same in very small and medium-sized villages. The research shows that the absence of schools is more typical to very small-sized villages than to medium-sized ones. As shown in Table 1, also the average population is larger in those villages where at least one school was active in 2013. Most Hungarian villages experienced a decline in population in the last two decades. The average net migration rate is negative in each type of settlements, so more people moved out than in of the villages. However, it is possible to say that villages with schools have more favorable values than those without a school.

The situation is the same in case of natural decrease and age profile of the population. The proportions of children and young adults are higher and the proportion of middle-aged and pensioners smaller in communities with schools. The ageing index is also unfavorable in each type of settlements, the lower values being recorded by small villages without schools. This means that the fertility rate and the percentage of families with children are higher in settlements with schools.

The research generated inconclusive results regarding school qualification of the population. The proportion of those who have not graduated

Tab. 1. Population characteristics of the Hungarian villages analyzed

\begin{tabular}{|c|c|c|c|c|}
\hline \multirow{2}{*}{ Population Characteristics } & \multicolumn{2}{|c|}{$\begin{array}{l}\text { Population } 500 \text { or } \\
\text { under }(N=1,062)\end{array}$} & \multicolumn{2}{|c|}{$\begin{array}{l}\text { Population } \mathbf{5 0 1} \text { to } \mathbf{2 , 0 0 0} \\
\qquad(N=1,233)\end{array}$} \\
\hline & $\begin{array}{l}\text { School } \\
(\mathrm{N}=78)\end{array}$ & $\begin{array}{c}\text { No School } \\
(\mathrm{N}=984)\end{array}$ & $\begin{array}{c}\text { School } \\
(\mathrm{N}=941)\end{array}$ & $\begin{array}{c}\text { No School } \\
(\mathrm{N}=292)\end{array}$ \\
\hline Average population number (capita), 2013 & 405 & 256 & 1,148 & 720 \\
\hline Average net migration rate (\%o), 2013 & -6.8 & -8.0 & -1.9 & -4.5 \\
\hline Average natural increase or decrease (\%), 2013 & -7.3 & -8.3 & -5.9 & -9.6 \\
\hline \multicolumn{5}{|l|}{ Age structure of the population (\%) } \\
\hline 18 years old and under (\%), 2011 & 20.5 & 18.0 & 19.7 & 18.5 \\
\hline 19-39 years old (\%), 2011 & 28.6 & 27.6 & 29.5 & 29.1 \\
\hline 40-64 years old (\%), 2011 & 33.8 & 35.4 & 34.4 & 35.0 \\
\hline 65 years old and over (\%), 2011 & 17.0 & 19.0 & 16.4 & 17.4 \\
\hline Ageing index (\%), 2013 & 126.7 & 178.9 & 119.9 & 142.7 \\
\hline Proportion of families with children (\%), 2011 & 65.8 & 63.5 & 66.2 & 65.8 \\
\hline Fertility rate & 1.9 & 1.8 & 1.8 & 1.7 \\
\hline \multicolumn{5}{|l|}{ School qualification of the population (\%) } \\
\hline didn't finish primary school (\%), 2011 & 19.0 & 16.7 & 17.0 & 15.7 \\
\hline primary school (\%), 2011 & 36.8 & 37.6 & 33.5 & 32.9 \\
\hline secondary school (\%), 2011 & 38.7 & 40.6 & 43.0 & 44.7 \\
\hline graduated (college, university) (\%), 2011 & 5.5 & 5.1 & 6.5 & 6.7 \\
\hline
\end{tabular}

Source: own calculation and edition based on Census, 2011 and HCSO, 2013 
primary school is higher, while the proportion of people having a secondary school certificate is smaller in villages with schools. The number of educated persons is higher in very small villages with schools, while it was smaller in small and medium-sized villages. The numbers are reversed for primary school dropouts (Table 1).

The analysis revealed that the presence of schools was associated with an appreciably smaller proportion of employed and inactive persons and higher percentages of unemployed and dependent compared to similar sized communities without a school (Table 2). The study also shows that the percentage of workers who commute is much larger in villages without a school.

Probably a consequence of a higher percentage of employed inhabitants, the income per capita from wages and other sources of income is also higher in settlements without a school. In contrast, the income from regular social assistance is higher in communities with schools. In accordance with this tendency, the average number of people

Tab. 2. Employment and welfare characteristics of the Hungarian villages analyzed

\begin{tabular}{lcccc}
\hline \multirow{2}{*}{ Employment \& Welfare } & \multicolumn{2}{c}{$\begin{array}{c}\text { Population 500 or } \\
\text { under (N=1,062) }\end{array}$} & \multicolumn{2}{c}{$\begin{array}{c}\text { Population 501 to 2,000 } \\
\text { (N=1,233) }\end{array}$} \\
\cline { 2 - 5 } & $\begin{array}{c}\text { School } \\
(\mathrm{N}=78)\end{array}$ & $\begin{array}{c}\text { No School } \\
(\mathrm{N}=984)\end{array}$ & $\begin{array}{c}\text { School } \\
\text { (N=941) }\end{array}$ & $\begin{array}{c}\text { No School } \\
\text { (N=292) }\end{array}$ \\
\hline Economic activity (\%) & & & & \\
\hline proportion of employed (\%), 2011 & 31.3 & 32.9 & 34.8 & 35.9 \\
\hline proportion of unemployed (\%), 2011 & 7.5 & 6.7 & 6.5 & 6.1 \\
\hline proportion of inactive earner (\%), 2011 & 34.3 & 37.8 & 33.2 & 33.7 \\
\hline proportion of dependent (\%), 2011 & 27.0 & 22.6 & 25.5 & 24.3 \\
\hline Proportion of workers who commute (\%), 2011 & 48.5 & 62.7 & 17.7 & 30.0 \\
\hline Per capita income (HUF/capita), 2013 & 551,926 & 562,891 & 626,429 & 648,066 \\
\hline Per capita income from wages (HUF/capita), 2013 & 516,375 & 520,315 & 589,699 & 609,492 \\
\hline $\begin{array}{l}\text { Per capita income from regular social assistance } \\
\text { (HUF/capita), 2013 }\end{array}$ & 2,577 & 1,808 & 1,672 & 1,333 \\
\hline $\begin{array}{l}\text { Average number of people receiving regular social } \\
\text { assistance (people), 2013 }\end{array}$ & 3.3 & 1.5 & 6.0 & 3.1 \\
\hline \begin{tabular}{l} 
Soln \\
\hline
\end{tabular}
\end{tabular}

Source: own calculation and edition based on Census, 2011 and HCSO, 2013

Tab. 3. Housing and Infrastructure characteristics in Hungarian villages

\begin{tabular}{|c|c|c|c|c|}
\hline \multirow{2}{*}{ Housing \& Infrastructure } & \multicolumn{2}{|c|}{$\begin{array}{l}\text { Population } \mathbf{5 0 0} \text { or under } \\
\qquad(\mathrm{N}=1,062)\end{array}$} & \multicolumn{2}{|c|}{$\begin{array}{l}\text { Population } \mathbf{5 0 1} \text { to } \mathbf{2 , 0 0 0} \\
\qquad(\mathrm{N}=1,233)\end{array}$} \\
\hline & $\begin{array}{l}\text { School } \\
(\mathrm{N}=78)\end{array}$ & $\begin{array}{l}\text { No School } \\
(\mathrm{N}=984)\end{array}$ & $\begin{array}{c}\text { School } \\
(\mathrm{N}=941)\end{array}$ & $\begin{array}{l}\text { No School } \\
(\mathrm{N}=292)\end{array}$ \\
\hline $\begin{array}{l}\text { Proportion of houses with all modern conveniences } \\
(\%), 2011\end{array}$ & 32.7 & 31.2 & 43.1 & 40.3 \\
\hline $\begin{array}{l}\text { Proportion of houses supplied by municipal water } \\
\text { system (\%), } 2011\end{array}$ & 82.5 & 83.1 & 87.3 & 88.8 \\
\hline $\begin{array}{l}\text { Proportion of houses supplied by municipal sewer } \\
\text { system (\%), } 2011\end{array}$ & 26.9 & 28.7 & 43.3 & 46.7 \\
\hline Proportion of houses built after 1990 (\%), 2011 & 10.0 & 9.7 & 13.5 & 12.0 \\
\hline
\end{tabular}

Source: own calculation and edition based on Census, 2011 and HCSO, 2013 
receiving regular social assistance is much higher in such villages (Table 2.).

As expected, the housing stock in rural communities with schools is somewhat newer and, in line with this fact, the proportion of houses with all modern conveniences is higher than in those without schools (Table 3).

However, the research findings concerning the infrastructure were different than expected. The study shows that rural villages without schools are more likely to be connected to the municipal water system and sewer system than those without schools. So, according to these results, with the exception of houses, infrastructure is more developed in communities without schools than those with schools (Table 3).

\section{Rural characteristics of Romania:}

The rural population recorded 9.21 million inhabitants in 2013, a figure that represents a percentage of $46.1 \%$ of the total population and shows a high degree of rurality in Romania. Along with a decrease in total population, Romania is facing a demographical aging, more pronounced in rural areas, due to the low birth rates and the migration phenomenon (Pocol, 2013) (Table 4). There was a sharp decrease of rural population between 1990-2011, especially for age groups 0-14 years and 15-29 years. Analyzing the age structure of the rural population in 2011, the most important segment was represented by the population between 40 and 64 years old (Table 4).

\section{School closures in the examined countries:}

The number of schools' units (primary and secondary education) is an important indicator that illustrates the level of education in Romanian rural area. Compared to 1997, the number of primary and secondary schools decreased from 11,201 to 2,823 units in 2013. In 1997, the percentage of primary and secondary schools from rural area represented $81.9 \%$ from the total number of primary and secondary schools at national level. In 2013 , the percentage decreased to $71.5 \%$. The territorial distribution of the villages with schools is shown in Figure 1 and 2.

There are some regions (mountains or hills areas) in Romania where there are a lot of small villages, with a low percentage of school-age population. In these regions, schools were closed, all the children being enrolled in schools from the communes' centres. It can be noticed in the Figure 2 that an important part of the population furthermore lives in villages with schools.

Figure 3 shows the proportion of Hungarian settlements which don't have primary schools or upper (5-8) classes. In 2012, 42\% of the settlements did not have primary schools, and in

Tab. 4. Population characteristics in Romanian rural area

\begin{tabular}{lc}
\hline Indicators & \\
\hline Average population number (capita), 2013 & 9214935 \\
\hline Average net migration rate (\%0), 2011 & 16.0 \\
\hline Average natural increase or decrease (\%), 2013 & -4.5 \\
\hline Age structure of the population (\%) & 22.7 \\
\hline 18 years old and under (\%), 2011 & 27.1 \\
\hline $19-39$ years old (\%), 2011 & 30.8 \\
\hline 40-64 years old (\%), 2011 & 19.4 \\
\hline 65 years old and over (\%), 2011 & 86.8 \\
\hline Graduates by level of education \%, 2011-2012 & 11.7 \\
\hline Primary and secondary education & 0.8 \\
\hline High school education & 0.6 \\
\hline Vocational education & 0.1 \\
\hline Post High school education &
\end{tabular}




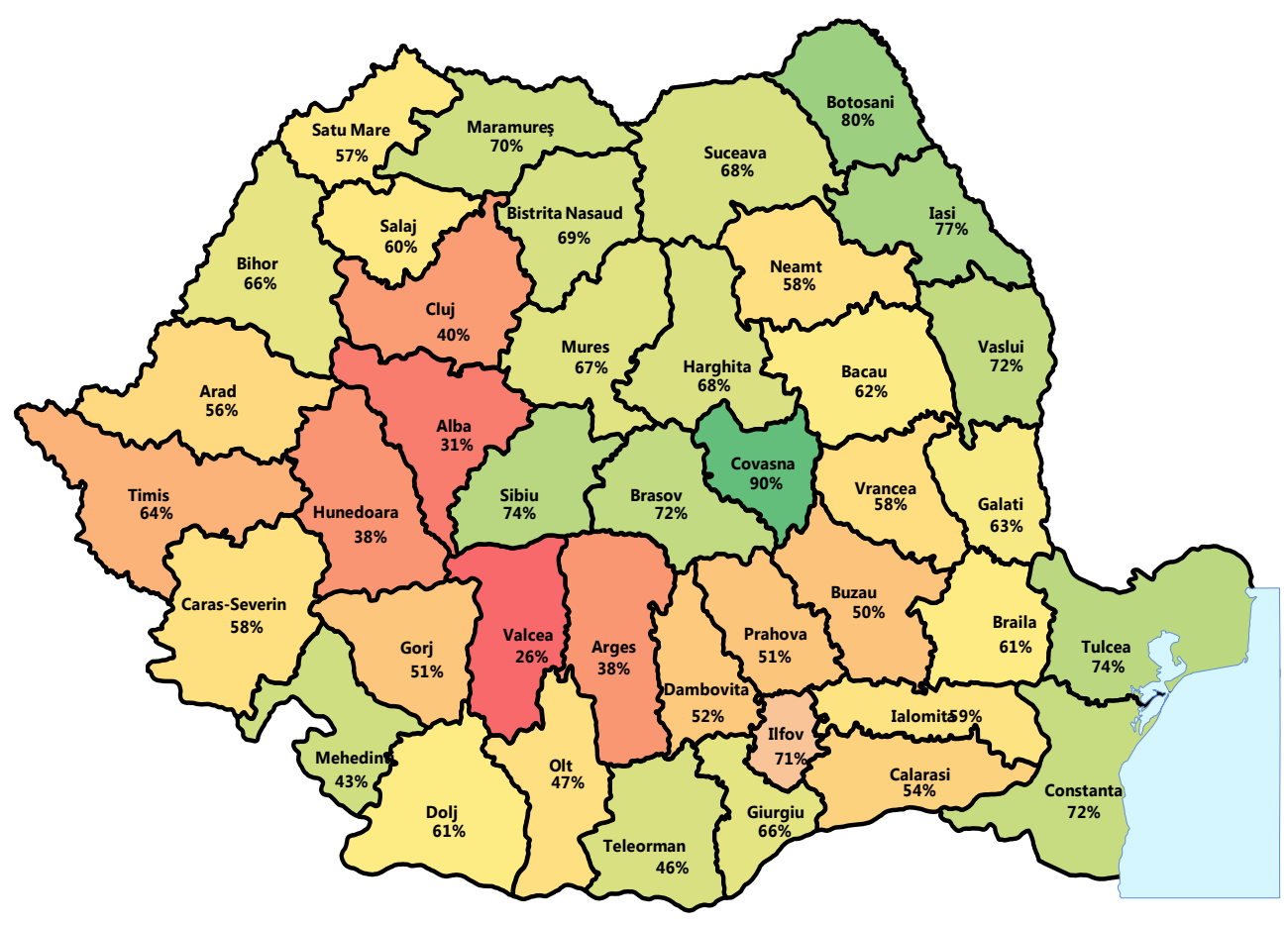

Fig. 1 Proportion of villages with schools (\%, county level)

Source: own edition based on data provided by the National Institute of Statistics, 2013

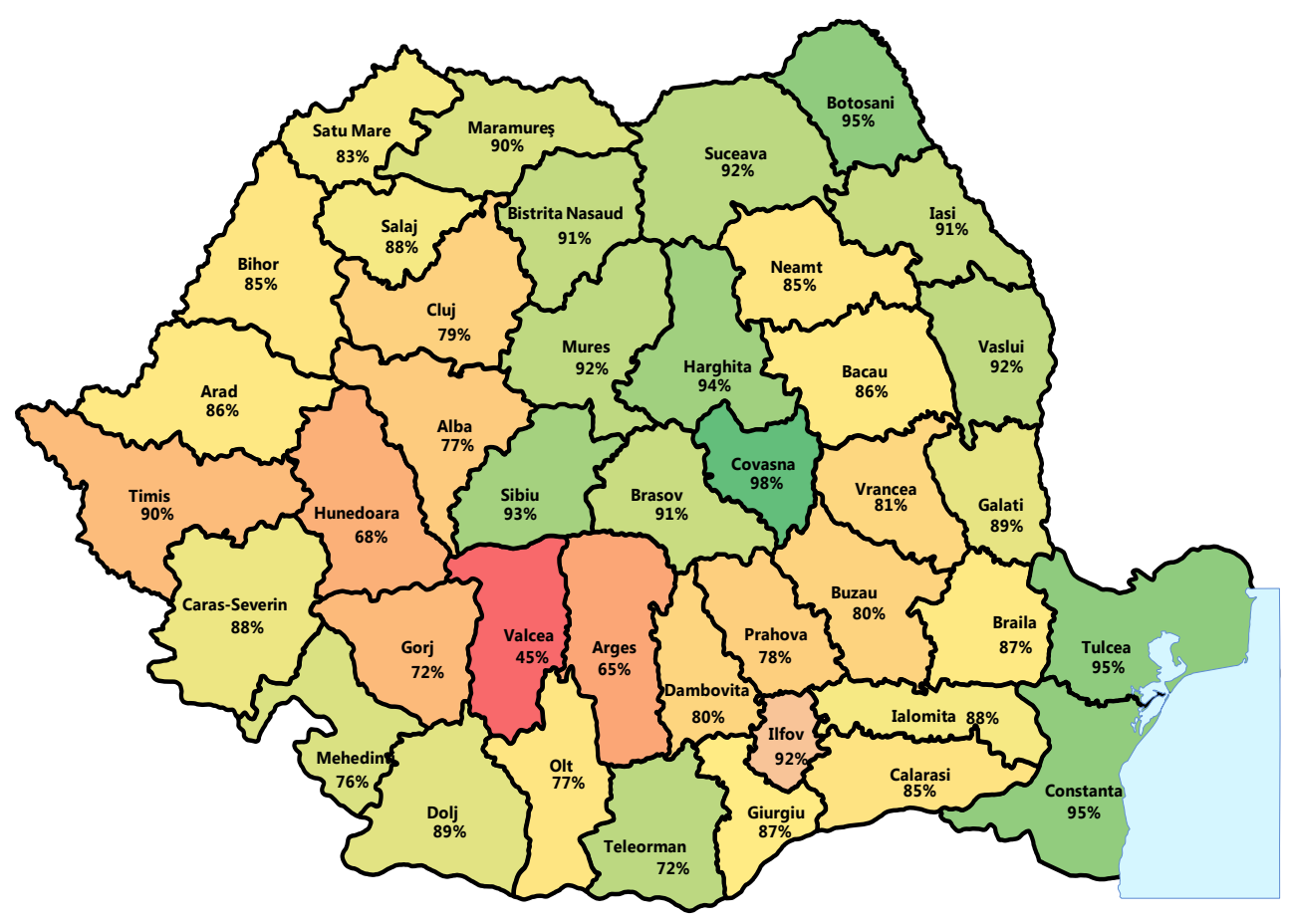

Fig. 2 Proportion of population who lives in villages with schools (\%, county level) Source: own edition based on data provided by the National Institute of Statistics, 2013 


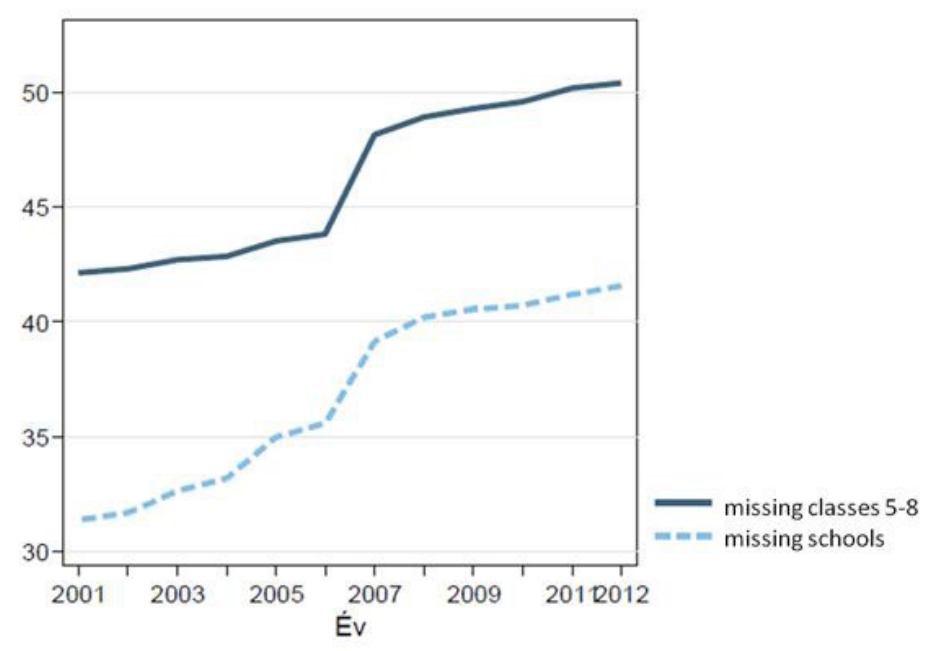

Fig. 3 Proportion of settlements without primary school in Hungary (\%) Source: Varga, 2015

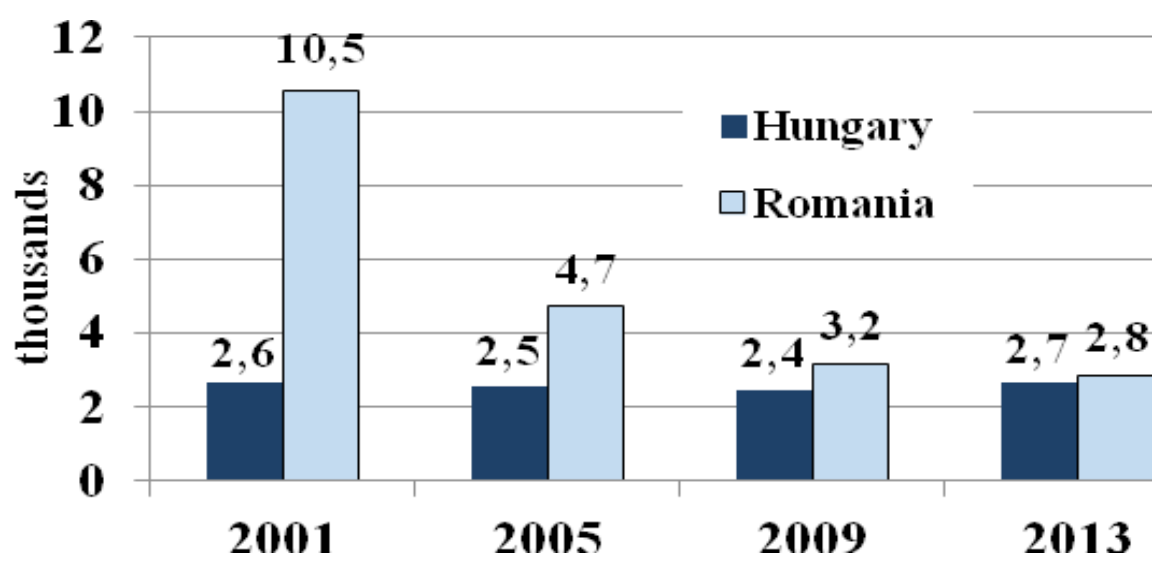

Fig. 4 Number of educational units in rural villages 2001-2013 (primary \& secondary schools)

Source: own edition based on data provided by the National Institute of Statistics, Romania and Hungarian Central Statistical Office, 2001-2013

every second settlement missed the upper classes. As it is demonstrated, there was a decreasing tendency. In the years 2006-2007, a significant number of settlements lost primary education facilities. This happened due to the minimum headcount requirements for schools as regulated by the new Public Education Act. In those villages, lived 5\% of 6-13-year-old pupils in 2012. Further $2,5 \%$ of pupils lived in villages, where only 1-4 classes existed (Varga, 2015).

Bódi and Fábián (2011) illustrate the situation on a similar way. Between May 2006 and 2009, 141 schools were closed in Hungary. $70 \%$ of these schools were in small and medium sized villages.
There was no demonstrable link between school closures and the physical characteristics of the schools. In the environment of consolidated schools there was another school, which was available for the parents. There was no significant correlation between the infrastructural condition (location inside of the settlement, the condition of the school building) and the evidence of school closure. Larger communities were more likely to take into consideration the socio-cultural background of the families affected. On that settlements such schools were closed, where the social background of pupils was unfavourable and 

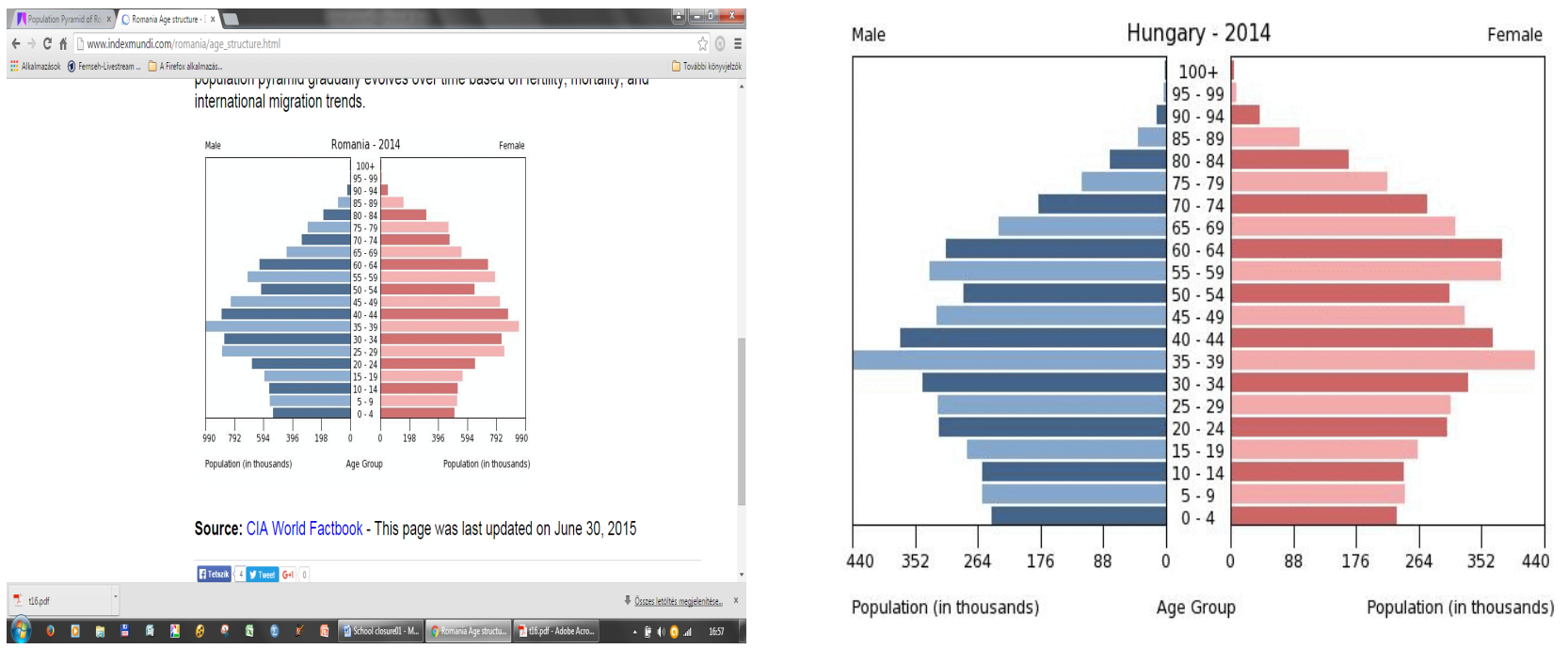

Fig. 5 Population Pyramid of Romania and Hungary (2014)

Source: CIA The World Factbook https://www.cia.gov/library/publications/the-world-factbook/geos/...

Tab. 5. Proportion of villages without schools in 2013 (\%)

\begin{tabular}{cccc}
\hline & pop. 500 or under & pop. between 501-1,000 & Total \\
\hline Hungary & 92.7 & 40.2 & 46.1 \\
\hline Romania & 70.2 & 22.9 & 56.1 \\
\hline
\end{tabular}

Source: own edition based on data provided by the National Institute of Statistics, Romania and Hungarian Central Statistical Office, 2013

the efficiency of the school was lower (Bódi and Fábián, 2011).

Comparing the Romanian and the Hungarian situation (fig. 4), the significant decrease of schools in Romania could have a demographic explanation as well. Analyzing the age groups of the countries (Fig. 5), it is possible to conclude that the decrease of birth is dramatically in Romania and somewhat steady in Hungary.

In the last years, however, the number of schools slightly increased in Hungary. The percentage of villages with schools in both categories of villages ( $1^{\text {st }}$ category under 500 inhabitants and $2^{\text {nd }}$ category between 501-1000 inhabitants) is higher in Romania (Table 5).

The abandon rate in primary and secondary education was oscillatory between 1997 and 2013 (between 1-3\%), but the biggest rate was registered in the case of secondary education in rural area. There is a correlation between the primary school dropout and the socio-economic situation of the population. This is the reason for which some socio-economic indicators of rural areas were analyzed.

\section{CONCLUSIONS}

Rural school closures happened in both countries in different periods and to a different extent. These closures usually affected negatively the villages, rural places having more chances to become isolated and to lose local identity as well as the possibility of future development activities.

In Hungary, villages with schools have better demographic performance, partly better living and infrastructural conditions, but the employment and the welfare characteristics are worse, compared to those without schools.

The decline of birth rates contributed to the consolidation of schools in both countries. In Romania the decline was rather explicit, in Hungary the enforcement of the new Education Act speeded up the closure of rural schools. In Romania, geographical conditions can influence school closures; in mountainous regions the 
possibility to close the local school is much higher. On the whole, the rural school closure affected much more the Hungarian villages than the Romanian ones.

\section{REFERENCES}

1. Autti O., Hyry-Beihammer E.K. (2014). School closures in rural Finnish communities. Journal of Research in Rural Education 29(1): 1-17. Retrieved from http://jrre.psu. edu/articles/29-1.pdf.

2. Balázsi I., Bódi, F. (2011). Iskolai teljesítmény - iskolai átszervezés 2006-2009 / School Performance - School Consolidation (In: Bódi Ferenc - Fábián Gergely: Helyi szociális ellátórendszer Magyarországon / Local Social Service System in Hungary. Debreceni Egyetemi Kiadó 2011).

3. Bódi F., Fekete A. (2011). A kereslet és kínálat változása az alapszintű oktatásban 1988-2009 / The Change of the Demand and Supply in the Primary Education 1988-2009 (In: Bódi, Ferenc-Fábián, Gergely (2011): Helyi szociális ellátórendszer Magyarországon/ Local Social Service System in Hungary. Debreceni Egyetemi Kiadó 2011.

4. Howley C., Johnson J., Petrie J. (2011). Consolidation of Schools and Districts:What the Research Says and What It Means. Boulder, CO: National Education Policy Center. Retrieved from http://nepc.colorado.edu/publication/ consolidation-schools-districts.

5. Lyson T. (2002). What Does a School Mean to a Community? Assessing the Social and Economic Benefits of Schools to Rural Villages in New York. Journal of Research in Rural Education 17(3): 131-137.
6. Mincu M. (2011). Rural Education in Hungary, Poland and Romania: An overview (Conference paper), ECER 2011, Urban Education. Retrieved from http:// www.eera-ecer.de/ecer-programmes/conference/5/ contribution/19145/.

7. Pocol C.B. (2013). Economie Rurală, Identitate și actualitate, Editura AcademicPres, Cluj Napoca, Romania: 23-26.

8. Popa S., Acedo C. (2006). Redefining professionalism: Romanian secondary education teachers and the private tutoring system. International Journal of Educational Development 26(1): 98-110.

9. Varga J. (ed.) (2015). A közoktatás indikátorrendszere (The indicator system of the public education) MTA Közgazdaságtudományi Intézet, Budapest.

10. Institutul Național de Statistică, Baza de date Tempo on line, Retrived from http://statistici.insse.ro/ shop/?page=info, last accession date $18^{\text {th }}$ of January, 2016.

11. Hungarian Central Statistical Office (HCSO). Retrieved from http://www.ksh.hu/, last accession date $10^{\text {th }}$ December, 2015.

12. Programul Național de Dezvoltare Rurală pentru perioada 2014-2020, Versiunea oficială 1 iulie 2014, http://www.madr.ro/docs/dezvoltarerurala/programare-2014-2020/PNDR_2014_2020_01.07.2014.pdf, last accession date $18^{\text {th }}$ of January, 2016.

13. UNICEF, 2012, Copiii care nu merg la școală. O analiză a participării la educație în învățământul primar şi gimnazial, http://www.unicef.ro/wp-content/uploads/ copiii-care-nu-merg-la-scoala-pt-web.pdf.pdf, last accession date 11th of February, 2016. 